5. Рояк, А.А. Психологический конфликт и особенности индивидуального развития личности ребенка / А.А. Рояк. - М.: Педагогика, 1988. - 117 с.

\title{
ИНФОРМАЦИОННАЯ КУЛЬТУРА КАК УСЛОВИЕ СОЦИАЛИЗАЦИИ ЛИЧНОСТИ ПОДРОСТКА
}

\author{
Ермолова B.O. \\ Научный руководитель: к.псх.н., доцент Макаревская Ю.Э.
}

В XXI веке невозможно представить межличностные коммуникации подростков без использования возможностей информационной технологий. Это уже не просто достижение науки и техники, информационные технологии неотъемлемая часть жизни, которая обеспечивает бесперебойные коммуникации с внешним миром. IT-технологии воздействуют на все сферы жизни подростка, в том числе на его интеллектуальное, психоэмоциональное развитие и социализацию личности в целом.

За последние 10 лет с появлением IT-технологий в мире стала складываться информационная культура. Тенденции, которые она задает, имеют повсеместное распространение в обществе и практически не поддаются контролю. Скорость распространения информации стала почти мгновенной, география информационной культуры не имеет границ. Дистанционность, отсутствие контроля и анонимность сделали информационную культуру привлекательной, опасной и глобальной. К числу возможностей, которые открывает информационная культура, добавились опасности и угрозы, приносящие ущерб для духовного и физического здоровья человека.

В существующих условиях информационной культуры наиболее актуальной становится проблема включения каждого человека в единую социально-информационную систему и саму структуру общества. Ключевым элементом данного процесса является социализация личности, позволяющая человеку стать полноценным членом общества.[2] Но учитывая современные реалии, это становится невозможным и недоступным в полном объеме без информационной компетентности, которая представляет собой «способность человека в полной мере осмыслить и использовать возможности информационного общества, всесторонне адаптироваться и самореализоваться в нем» [3, с. 37-43].

Говоря об информационной компетентности, необходимо учитывать ее значимость в процессе социализации подростка: чем более человек информационно компетентен, тем он становится более востребованным в информационном обществе. Информационная компетентность приобретается человеком и совершенствуется как индивидуально, так в условиях социальных институтов при соответствующем образовании. Таким образом, именно информационная компетентность становится главным условием успешной социализации личности подростка в новой информационной среде общества.

Кроме того, информационная культура и в целом оказывает влияние на каждую из основных фаз процесса социализации личности подростка. Так на первой фазе, которая заключается в освоении социальных ценностей и норм 
происходят самые глобальные изменения [6]. Информационная культура диктует новые ценности подросткам, которые они впитывают посредством каналов массовой информации. Теперь «знание, информация, образование выступают системообразующими ценностями. Образ превращается в самостоятельную ценность: с одной стороны как образ, отражающий реальность, с другой - как симулякр или мнимость, т.е. образ, за которым не стоит никакая реальность. Идеальные ценности начинают доминировать над материальными. Ценности (экономические, политические, эстетические) становятся все более доступными для человека. Плюрализм выступает как неотъемлемая черта системы ценностей информационного общества» [4].

Помимо этого изменения происходят и на второй фазе процесса социализации, которая заключается в стремлении личности к собственной персонализации, самоактуализации и определенном воздействии на других членов общества.[6] Все вышеперечисленные процессы происходят преимущественно в виртуальной реальности, то есть личность проявляет себя в поле интернет-коммуникаций. В результате происходит следующие изменения:

- Личное общение замещается дистанционным посредством социальных сетей - происходит трансформация общения, снижается уровень владения коммуникативными навыками в реальной жизни.

- Происходит переход развития личности в социуме, к индивидуальному развитию, то есть получение новых знаний, навыков и умений происходит опосредованно и теряется при этом преемственность поколений.

- Появляются негативные последствия социализации личности в информационной культуре.

- Во-первых, повышение уровня агрессии у детей и подростков как последствия воздействия агрессивных компьютерных игр на психику человека.

- Во-вторых, отмечается притупление инстинкта самосохранения за счет обесценивание человеческой жизни, в том числе и своей, растет в сознании иллюзия бессмертности, «второго шанса», пропагандируемого играми.

- В-третьих, происходящая виртуализации реальности способствует смене жизненных приоритетов реального мира на виртуальные несуществующие ценности такие как, перманентная жажда социального поощрения, мгновенной славы и «хайпа». И, как следствие, появление интернет-зависимости, в результате которой подростки реализуют все социальные потребности личности в поле интернет-коммуникаций.

- Для третьей фазы процесса социализации, заключающейся в интеграции каждого человека в определенную социальную группу для раскрытия своих собственных особенностей и возможностей, свойственен выбор приоритетной социальной группы в числе интернет-сообществ. По этой причине раскрытие потенциала личности, eе субъектность носит поверхностный, кратковременный характер.

Например, появление вместо журналистов, как специалистов в сфере массовой информации, блогеров, абсолютно не компетентных, необразованных 
в данном направлении, не несущих ответственность за свои действия активистов в поле интернет-коммуникаций. Блогер - это продукт информационного общества, отвечающий всем его требованиям: динамичность, владение актуальной информацией и скорость реагирования на нее, доступность для каждого, соответствие социальным ожиданиям и трендам.

Информационное общество открыло для подрастающего поколения невероятные обширные возможности, но вместе с этим внесло свои коррективы в развитии и становление личности подростка.

Информационная культура на сегодняшний день оказывает самое большое влияние на формирование новой системы ценности и духовно-нравственного ориентира, путем использования информационных каналов для единовременного воздействия на сознание большого количества подростков. Также происходит трансформация механизма социализации личности подростка за счет виртуализации социальных институтов и появления коммуникационных интернет-площадок на базе социальных сетей [5].

Виртуализация реальности - это неизбежный этап в развитии информационной культуры, суть которого создание искусственного мира с новыми законами и нормами общественного поведения, а также вытеснение реального мира с его ценностями.

\section{Литература}

1. Грехнев В.С. Информационное общество и образование // Вестник Московского университета. Серия 7. Философия. № 6. 2006. С. 88-106.

2. Козлова, Н. С. (2009) Социально-психологические детерминанты восприятия реализованности собственного потенциала личностью: Дис. ... канд. психол. наук: 19.00.05. Кострома.

3. Петрова Е.В. «Информационная компетентность в образовании как залог успешной адаптации человека в информационном обществе» Информационное общество, 2012 вып. 2, с. 37-43.

4. Зайцева Л.А. «Человек в системе ценностей информационного общества» автореферат диссертации по философии, специальность ВАК РФ 09.00.11, Москва 1999г.

5. Иванов Д.В. Виртуализация общества. Версия 2.0. СПб.: Петербургское востоковедение, 2002. 224 с.

Интернет-источники

6. Все о психологии. Психология, статьи по психологии. «Социализация личности. Этапы социализации личности»//URL:http://www.edupsycho.ru/socializaciya-lichnosti.html

7. Желада Т.Н., Багровская О.В., «Человек и его ценности в информационном http://www.promgups.com/kafedra/?page_id=384 обществе»//URL:

ЭВРИСТИЧЕСКИЕ СЛЕДСТВИЯ ПРОФИЛАКТИЧЕСКОЙ

РАБОТЫ С МЛАДШИМИ ШКОЛЬНИКАМИ С ПРИМЕНЕНИЕМ ПРОЕКТИВНЫХ МЕТОДОВ

Зинатуллина А.П., Тесля С.Н. 